\title{
A.13 Private collection Ms., Kathmandu = NGMPP E 614-327
}

A Nepalese paper manuscript of 295 folios. Seemingly undated.

1. Saptaśatikā-prajñāpāramitā [163]

2. Abhisamayālaṃkāra-nāma-prajñāpāramitopadeśaśāstra ${ }^{28}$

3. Prajñāpāramitā-dhāraṇī $[8,56]$

4. Pìtavarṇa-prajñāpāramitā-dhāraṇī [55,162]

5. Prajñāpāramitā-dhāraṇī $[8,56]$

6. Șaṭpāramitā-hṛdaya-nāma-dhāraṇī [59]

7. Vairocanì-nāma-dhāraṇi [3]

8. Akṣobhya-nāma-dhāraṇi [4]

9. Ratnasambhava-nāma-dhāraṇī [5]

10. Amitābha-nāma-dhāraṇī [6]

11. Amoghasiddhi-nāma-dhāraṇī [7]

12. Durgatipariśodhanī-nāma-dhāraṇī [45,74]

13. Sākyamuni-nāma-viśeșa-dhāraṇī [35]

14. Sarvajñatāmukhapraveśa-nāma-dhāraṇī [53]

15. Nāmasaṃīti-dhāraṇī [115]

16. Aparimitāyur-nāma-dhāraṇī [47]

17. Pañcaviṃśatikā-prajñāpāramitā-nāma-dhāraṇī [101]

18. Pītavarṇa-prajñāpāramitā-dhāraṇī [55,162]

19. Gạ̣ḍavyūha-nāma-dhāraṇī [9]

20. Daśabhūmīśvara-nāma-mahāyānasūtra [10]

21. Lan̉kāvatāra-nāma-dhāraṇī [12]

22. Saddharmapuṇdarīka-mantra-dhāraṇī [13]

23. Tathāgataguhya-nāma-dhāraṇī [14]

24. Lalitavistara-trapuṣabhallikaparivartana-kalyāṇavākya [15]

25. Suvarṇaprabhāsottama(...)saṃdhāraṇiparivarta [16]

26. Amoghapāśa-nāma-hṛdaya-mahāyānasūtra [63]

27 After the NGMPP/NGMCP online catalogue description:https://catalogue.ngmcp.uni-hamburg. de/servlets/solr/select?q=\%2BobjectType $\% 3 \mathrm{~A} \% 22$ ngmcpdocument $\% 22+\% 2$ BallNGMCP $\% 3 \mathrm{~A}$ * +\%2Bmicrofilm_series $\% 3 \mathrm{~A} \% 22 \mathrm{E} \% 22+\% 2 \mathrm{Bmicrofilm} \_$reel $\% 3 \mathrm{~A} \% 22614 \% 22+\% 2 \mathrm{Bmicrofilm}$ ent ry $\% 3 \mathrm{~A} \% 223 \% 22 \& \mathrm{fl}={ }^{\star} \% 2 \mathrm{Cscore} \&$ rows $=10 \&$ version $=4.5 \&$ mask $=$ content $\% 2 \mathrm{Fsearch} \% 2 \mathrm{Fsimple}$. xed\&sort=id+asc (accessed March 2020). I have not been able to consult the original manuscript or any reproductions. Titles given with minor standardizations. Corresponding text numbers in Cambridge Ms. Add. 1326 are given in square brackets (there is a chance of inconsistencies in the case of texts which appear by the same title more than once).

28 Cf. Matsunami 1965: 148-149 for such beginnings.

2 Open Access. (C) 2021 Gergely Hidas, published by De Gruyter. (cc) BY-NC-ND This work is licensed under the Creative Commons Attribution-NonCommercial-NoDerivatives 4.0 International License. https://doi.org/10.1515/9783110713367-016 
27. Maitreyapratijñā-nāma-dhāraṇī [87]

28. Amoghapāśa-nāma-hṛdaya-mahāyānasūtra [63]

29. Mañjughoṣakṛti-praṇidhānarāja [88]

30. Sahasrabhujalokeśvara-dhāraṇī [66]

31. Siṃhanādalokeśvara-vyādhipraśamaṇī-dhāraṇī [64]

32. Avalokiteśvaramukhodgīinna-siddhikā-nāma-dhāraṇī [69]

33. Avalokiteśvara-nīlakaṇṭha-nāma-dhāraṇī [67]

34. Sahasrāvarta-nāma-dhāraṇī [68]

35. Ṣaḍakṣarī-mahāvidyā-nāma-dhāraṇī [69]

36. Bhadracari-mahāpraṇidhānarāja [70]

37. Mokṣaprada-nāma-dhāraṇī [71]

38. Abhayaṃkarī-nāma-dhāraṇī [72]

39. Maṇibhadra-nāma-dhāraṇī [73]

40. Vajrapāṇi-mahārakṣā-nāma-dhāraṇī [49]

41. Herukasarvarogapraśamanī-nāma-dhāraṇī [144]

42. Cūḍābhagavatī-dhāraṇī [75]

43. Hutāśanatejo-nāma-dhāraṇī [37]

44. Bhaiṣajya-nāma-dhāraṇī [42]

45. Mañjuśrīpratijñā-nāma-dhāraṇī [58]

46. Mañgala-nāma-dhāraṇī [43?]

47. Upamahasta-nāma-dhāraṇī

48. Mañgala-nāma-dhāraṇī [43?]

49. Karṇajāpā-nāma-dhāraṇī [40]

50. Sarvapāpadahanī-nāma-dhāraṇī [41]

51. Yakṣāșțaka [60]

52. Jambhalajalendra-nāma-dhāraṇī [61]

53. Vasudhārā-nāma-dhāraṇī [62]

54. Cintāmaṇimudrāhṛdayāparājitā-mahādhāraṇī

55. Pratisarāmahāvidyā-dhāraṇī [76]

56. Pratisarākalpa-dhāraṇi [77]

57. Mahāsāhasrapramardanī-nāma-dhāraṇī [78]

58. Mahāmāyūrī-vidyārājñī-nāma-dhāraṇī [79]

59. Mahās̄ìtavatī-nāma-vidyā-dhāraṇī [80]

60. Mahāmantrānusāriṇī-mahāvidyā-nāma-dhāraṇī [81]

61. Sarvatathāgatoṣnịṣasitātapatra-nāmāparājitā-pratyañgirā-mahāvidyārājñ̄ [83]

62. Mūlavidyā-nāma-dhāraṇī [1]

63. Śatākṣara-nāma-dhāraṇi [2]

64. Sapane-vidyā-dhāraṇī [84]

65. Jātismara-nāma-dhāraṇī [36] 
66. Parṇaśabarī-mahāmārīpraśamanī-nāma-dhāraṇī [85]

67. Hemāñgī-nāma-dhāraṇī [86]

68. Samādhirājaguhyottaraparamatantrādiprameyaphala

69. Tārāpratijñā-nāma-dhāraṇī [89]

70. Dhvajāgrakeyūra-nāma-dhāraṇī [90]

71. Gāthādvaya-nāma-dhāraṇī [43]

72. Ṣạ̣mukhī-nāma-dhāraṇī [44]

73. Mahāmāyāvijayavāhinī-nāma-dhāraṇī [91]

74. Varṣāpana-vidhi

75. Sūryanāma-sahasra

76. Kurukullā-nāma-dhāraṇī [95]

77. Jāngulī-nāma-dhāraṇī

78. Mārīcī-nāma-dhāraṇī [92]

79. Vajrasarasvatī-sādhana [93]

80. Vajravairocanī-stava [96]

81. Ușṇīṣacakravartī-nāma-dhāraṇī [50]

82. Vajravidāraṇa-hṛdaya-mantra-dhāraṇī [98]

83. Gaṇapati-hṛdaya-nāma-dhāraṇī [99]

84. Uṣṇịṣavijayā-nāma-dhāraṇī [100]

85. Mārīcī-nāma-dhāraṇī [102]

86. Grahamātṛkā-nāma-dhāraṇī [103,177]

87. Vajragandha-nāma-dhāraṇī [104]

88. Mahāmāyāvajravārāhī-nāma-dhāraṇī [105]

89. Cintāmaṇi-nāma-dhāraṇī [33,109]

90. Cundābhaț̣̄āikā-rakṣāmantra [110]

91. Ekajațā-nāma-dhāraṇī [113]

92. Grahamātṛkā-nāma-dhāraṇī [103,177]

93. Daśakrodhamahābhairava-nāma-dhāraṇī [114]

94. Avalokiteśvaramukhodgīrṇā-siddhinikā-nāma-dhāraṇi [116]

95. Amṛtabhakṣā-nāma-dhāraṇī [117]

96. Așțamahābhayaharaṇatārā-nāma-dhāraṇī [118]

97. Yogāmbarakarmarāja-nāma-dhāraṇī [120]

98. Sarvalokeśvara-dhāraṇī [121]

99. Khasarpaṇa-nāma-dhāraṇī [122]

100. Arapacanamañjuśrī-nāma-dhāraṇī [123]

101. Maitreya-nāma-dhāraṇī [124]

102. Saddharmapāṭha-dhāraṇī [125]

103. Vajratārā-nāma-dhāraṇī [126]

104. Ugratārā-nāma-dhāraṇī [127]

105. Daśakrodhānāṃ dhāraṇī [128] 
106. Lokapāla-nāma-dhāraṇī [129]

107. Gaganakṣepavajrayoginī-nāma-dhāraṇī [130]

108. Raktayamāri-nāma-dhāraṇī [131]

109. Prasannatārā-nāma-dhāraṇī [132]

110. Mahābhairava-dhāraṇi [133]

111. Siddhivighneśvara-dhāraṇī [134]

112. Mahākāla-dhāraṇī [135]

113. Gaṇeśaṣodaśa-nāma [136]

114. Vasudhāraṇy-upadeśa [137]

115. Mañjuśrībhațțāraka-nāma-dhāraṇī [58]

116. Puṇyavivardhana-nāma-dhāraṇī [138]

117. Sạ̣akṣarī-dhāraṇī [139]

118. Sarvajñajinadhāturatnakaraṇḍaka-nāmāvalokiteśvara-stotra [140]

119. Vajragandhārī-nāma-dhāraṇī [141]

120. Kālacakranibaddha-dhāraṇī [142]

121. Hevajradhāraṇapūjā-vidhi-saṃgraha [143]

122. Mahāsarasvatī-dhāraṇī [94]

123. Mahāpratisarā-dhāraṇi [145]

124. Mahāpratisarā-sādhana [146]

125. Mahāmāyūrī-dhāraṇī [147]

126. Mahāsāhasrapramardanī-sādhana [148]

127. Mahāśītavatī-sādhana-nāma-dhāraṇī [150]

128. Pañcarakṣāmahādevī-sādhana [151]

129. Pañcarakṣāmahādevī-sādhana [151]

130. Hastapūjā-vidhāna [152]

131. Nairātmā-sādhana-dhāraṇī [153]

132. Vajrahūṃkārabhairava-dhāraṇī [154]

133. Hayagrīva-dhāraṇī [155]

134. Hayagrīvabhairava-dhāraṇī [156]

135. Bhūtaḍāmarasaṃkṣipta-dhāraṇī [157]

136. Gaganātmajaśuklavarṇavajravārāhī-nāma-dhāraṇī [158]

137. Vajrayoginī-nāma-dhāraṇī [159]

138. Vajraśrnnkhalā-nāma-dhāraṇī [160]

139. Saṃkṣipta-dvibhujaheruka-nāma-dhāraṇī [161]

140. Vasudhārā-dhāraṇī [165]

141. Sitātapatrāparājitā-nāma-dhāraṇī [166]

142. Vajracarcikā-nāma-dhāraṇī [167]

143. Dhvajāgrakeyūra-sādhana-dhāraṇī [168]

144. Uṣnịịavijayā-sādhana-dhāraṇī [169]

145. Mahāmāyā-nāma-dhāraṇī [170] 
146. Vajrajvālānalārka-dhāraṇī [171]

147. Caṇdamahāroṣaṇa-dhāraṇī [172]

148. Mahāsaṃvarakarmarājaviśuddhi-nāma-dhāraṇī [173]

149. Hevajra-nāma-dhāraṇi [174]

150. Svalpākṣarā-bhagavatī-prajñāpāramitā [164]

151. Trailokyavijayā-nāma-dhāraṇī [175]

152. Lokātīta-stava [176]

153. Pịthā-stava-stotra [178]

154. Sanaiścara-stava [180]

155. Sarvajñatākāra-dhāraṇī [53]

156. Tārābhațtārikā-nāmāṣțottaraśataka 